\title{
Cycling policy in strategic documents of Polish cities
}

\author{
Michał Adam Kwiatkowski ${ }^{1}$ (D) . Daniela Szymańska ${ }^{1}$
}

Received: 1 December 2019 / Accepted: 15 October 2020 / Published online: 13 November 2020

(c) The Author(s) 2020

\begin{abstract}
Cycling transport fits well into the principles of sustainable development of cities and regions. Cycling policy is more and more often reflected in various strategic documents which are to set out measures to increase the share of cycling in urban transport. The paper evaluates the manner of implementing the assumptions of sustainable transport through the analysis of strategic documents from Polish cities of 100,000 and more inhabitants. The study was carried out in four stages. Firstly, the authors reviewed literature and reference material, i.e. strategic documents at European and national level. In the second stage, they analysed the strategies of urban development, indicating areas of urban development in which issues related to cycling were placed. The third phase focused on the additional (substantive) strategic documents related to transport and cycling-urban cycling policies. The task here was to assess their completeness and conformity with the guidelines of the European Commission concerning the creation of cycling policy. In the last stage of the study, the authors assessed whether measures for the development of cycling infrastructure were implemented in the studied cities: changes to the cycling infrastructure of the said cities were analysed by determining the dynamics of changes in the length of cycle paths and the availability of bicycle-sharing systems. The study showed the cohesion of cycling policies of Polish cities with higher-level (European and national) documents. It was also confirmed that in the majority of analysed documents the passages concerning cycling are prepared in the context of urban transport.
\end{abstract}

Keywords Bicycle $\cdot$ Sustainable transport $\cdot$ Cycling $\cdot$ Cycling infrastructure $\cdot$ Cycling policy $\cdot$ Poland

Michał Adam Kwiatkowski

kwiat@umk.pl

Daniela Szymańska

dani@umk.pl

1 Department of Urban and Regional Development Studies, Faculty of Earth Sciences and Spatial Management, Nicolaus Copernicus University in Toruń, ul. Lwowska 1, 87-100 Toruń, Poland 


\section{Introduction}

The introduction of sustainable urban transport principles is one of the more important challenges facing cities today. The negative impact of motorised modes of transport on the urban environment is increasingly visible in urban areas and is gaining recognition from city authorities, which is reflected in transport policies. One of the possible solutions to the problem may be the development of cycling, which is an emission-free and environmentally friendly form of mobility. In order to systematise the issues of cycling measures in transport, local authorities decide on a kind of contract with the citizens and a commitment to implement measures expressed in the form of urban cycling policies. In the documents created within the framework of this policy, the authorities diagnose problems in the development of cycling from the point of view of:

- transport, communication and mobility;

- tourism, recreation and sports;

- health;

- safety;

- quality of life and spatial order.

Priorities for action to improve the situation of cyclists are also defined.

The aim of the paper is to indicate how Polish cities implement the assumptions of sustainable urban transport in the context of the introduction of appropriate provisions concerning cycling policy, whether cycling policy is reflected in general documents, whether there are additional thematic strategies devoted to the issues of cycling transport. Assuming that the provisions of urban cycling policies are consistent with higher-level documents at the European and national level, the paper assesses to what extent cycling policies implement urban transport policy and to what extent they relate to other areas of life in the city. In addition, the article also verifies whether cities in Poland adopt measures for the development of urban cycling infrastructure, and if so, to what extent.

\section{Review of literature and documents}

Cycling policy of towns and cities is an increasingly popular problem addressed by researchers and presented from various perspectives (Kwiatkowski 2018b). Numerous studies indicate the role of cycling in urban transport as an element of active mobility with a positive impact on social life in cities. Research has shown that local authorities are paying increasing attention to cycling in urban transport, recognising that it offers many advantages for cities and their citizens. Due to the range of benefits it offers, cycling policy is a very effective element in promoting active mobility (Ton et al. 2018), including cycling, which responds to the need to improve the quality of the environment and reduce the impact of social exclusion in cities (Arsenio et al. 2016). Active mobility brings benefits not only for urban transport but also for the health of residents (Rojas-Rueda et al. 2011; Mueller et al. 2015; Ricci 2015; Johansson et al. 2017; Mueller et al. 2018; Otero et al. 2018). Classifying cycling within active mobility also allows policy-makers to combine the provisions of cycling policy with the health policy of the city (Perez et al. 2017; Bloyce and White 2018). 
Researchers also emphasise administrative activities as an important part shaping cycling policy. However, cycling needs organisational, political and financial support (Butterworth and Pojani 2018). Local cycling policies are implemented more effectively when their provisions can refer to national recommendations in this respect (Gaffron 2003). The success of a cycling policy also results from appropriate planning, evaluation of activities and reactions to the opinions of users of implemented solutions (Buehler et al. 2017a, b). Designing a cycling strategy in the form of guidelines without concrete solutions significantly reduces its effectiveness (Bloyce and White 2018). Cycling policy should therefore be a comprehensive and coherent set of complementary solutions, because only in this way can its provisions be enforced and cycling in urban transport effectively promoted (Pucher and Buehler 2008; Pucher et al. 2010).

In the literature, it is also highlighted that cycling policies focus primarily on the development of cycling infrastructure (Buehler and Dill 2015). However, the main task of cycling policy should be to ensure the safety and comfort of cycling journeys. In this context, it seems pivotal to give cyclists a privileged position in urban transport by creating appropriate conditions for mobility (Wang 2018). According to cycling policies, safety and equality in transport is to be ensured by cycling infrastructure separated from car traffic (Aldred and Dales 2017; Pucher and Buehler 2008).

The problem of insufficiently developed infrastructure is not the only obstacle to popularising cycling. The strong city-dwellers' habit of using motorised modes of transport is one of the biggest barriers to the promotion of cycling (Aldred et al. 2017; Wang 2018). Thus, the tools used to support cycling include methods to discourage or hinder car traffic (Tapp et al. 2016). A transport policy designed to reduce car traffic should make driving more troublesome for the user by extending distance, restricting the availability of certain areas and reducing the profitability of using the car (Buehler et al. 2017a; FernandezHeredia et al. 2014), including by imposing additional charges on car drivers (Olsson and Davis 2017; Munoz and Anguita 2018). As Piatkowski et al. (2015) point out, such methods should not be used without actions indicating and promoting alternative forms of transport. Activities promoting cycling constitute one of the crucial elements popularising this form of transport, especially in countries with less-developed cycling culture (Pojani et al. 2017). Cycling policy should clearly emphasise the independence of bicycle transport, promote increased physical activity and a sense of beneficial influence on the environment (Rerat 2018). Mobility training should also be provided to the youngest residents so as not to perpetuate the notion that the car is the primary traffic participant (Jordi-Sanchez 2018). Creating a well-perceived and effective cycling policy requires the involvement and coordination of both local authorities and inhabitants (Pucher et al. 2011a) who are users of the cycling infrastructure (Iwińska et al. 2018). An extremely important role in the creation of cycling policy is also played by representatives of non-governmental organisations (Spinney 2010; López and Montero 2018). Actions for cycling expressed in a specific cycling policy also shape the image of this form of transport (Jensen 2013).

Referring to the documents which were the subject of our analysis, it should be emphasised that the background for the introduction of local cycling policies is formed by documents adopted at higher levels. Cycling policy is reflected in strategic documents at different levels:

- European,

- national,

- regional

- urban (local). 
The provisions of local cycling policies should be in line with those of higher-level documents (Fig. 1).

European strategic documents raise the issue of the development of cycling in a multimodal form in combination with public transport (EU Cycling Strategy; EU Green Paper). Indications concerning infrastructure aim at making it safe and of high quality, which encourages citizens to use it in everyday commuting (EU Green Paper). Cycling is indicated as an ecological and sustainable form of transport (EU White Paper, Pact of Amsterdam). European strategic documents also postulate the need to inform the public about the positive impact of cycling on the environment. Provisions related to cycling are also present in Polish strategic documents at the national level. The National Development Strategy 2020 draws attention to the need to promote cycling and walking as forms of environmental protection and prevention of congestion in cities. The National Spatial Planning Concept emphasises the need to provide safe and secure parking spaces for bicycles and recommends the introduction of public bike-sharing schemes in cities. The National Urban Policy 2023 indicates that the development of pedestrian and bicycle traffic implements the objective of preventing the effects of uncontrolled suburbanisation. The need to invest in the development of cycling infrastructure and promotion of cycling has also been articulated in the National Transport Policy 2006-2025. Cycling policy is becoming the subject of strategic documents also in individual regions. Due to the scope of activities of voivodeship (NUTS-2) local governments, the provisions of these policies most often concern ensuring cohesion in the development of infrastructure in the region, integration of individual local governments in the implementation of measures for cycling and cycling tourism.

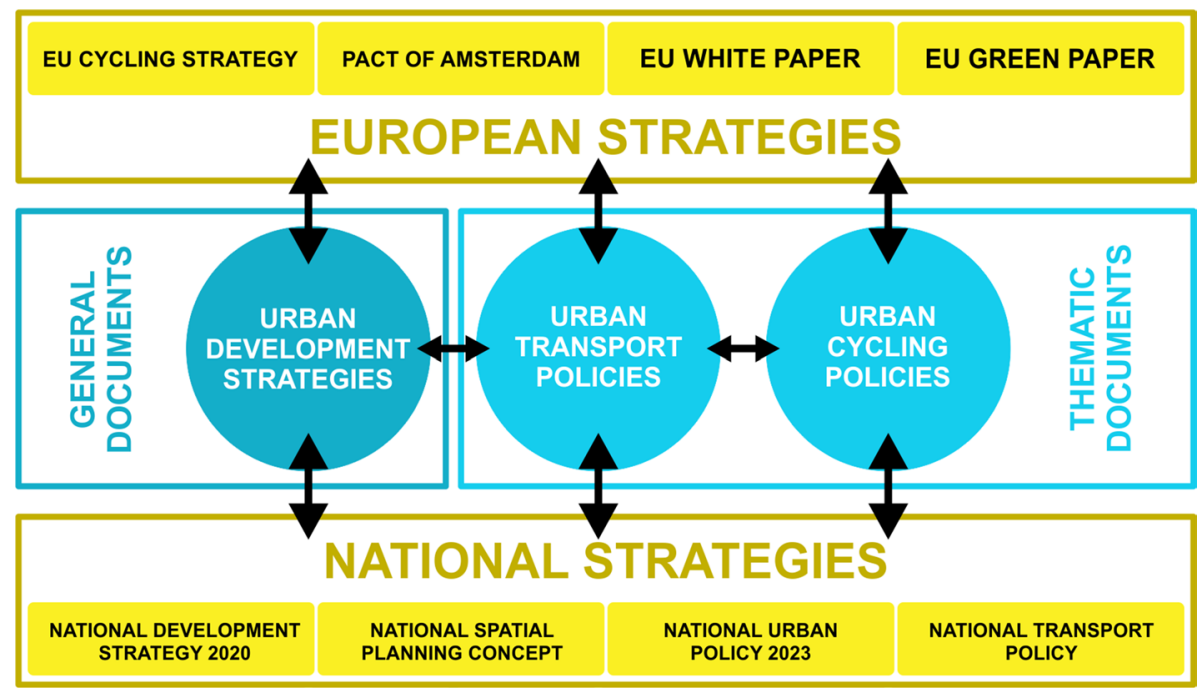

Fig. 1 Coherence of general and thematic documents with European and national strategies. Source: own elaboration based on: EU Cycling Strategy, Pact of Amsterdam, EU White Paper, EU Green Paper, Poland's National Spatial Planning Concept, Poland's National Transport Policy, Poland's National Urban Policy 2023, Poland's National Development Strategy 2020 


\section{Research methods}

The study was performed in four stages (Fig. 2). In the first stage, the literature (over 50 articles) and sources - strategic documents at the European and national level (8)-were reviewed in order to determine the basis for actions in favour of cycling described in strategic documents. The content of these documents was analysed so that the consistency of the urban cycling policies with the provisions of higher-level documents could be assessed in the subsequent stages.

In the second stage of the study, the provisions of the urban development strategies were analysed (39 cities), and first of all it was determined whether there are provisions related to cycling policy and which thematic areas they refer to.

Five clearly delineated areas were identified on the basis of the document search: transport, communication and mobility; tourism, recreation and sports; health; safety; quality of life and spatial order. In the third stage, the authors analysed additional thematic strategic documents concerning transport policies of cities and documents relating to cycling (20 cities). The issues considered here included sustainable transport strategies, cycling policies, concepts for the development of cycling networks, etc. At this stage of the study, it was verified whether the content of the documents corresponds to the recommendations of the European Commission on good practices in the implementation of cycling policy. An assessment was made of whether the elements mentioned by the Commission were included in each of the documents examined. The analysis focused on the presence of 12 elements contained in the EU guidelines:

- vision and strategy statement-it was assessed whether the implementation of cycling policy has a set and clearly specified objective which integrates the proposed measures,

- targets for cycling - it was checked whether the targets specified in the documents refer to specific measures for the development of cycling,

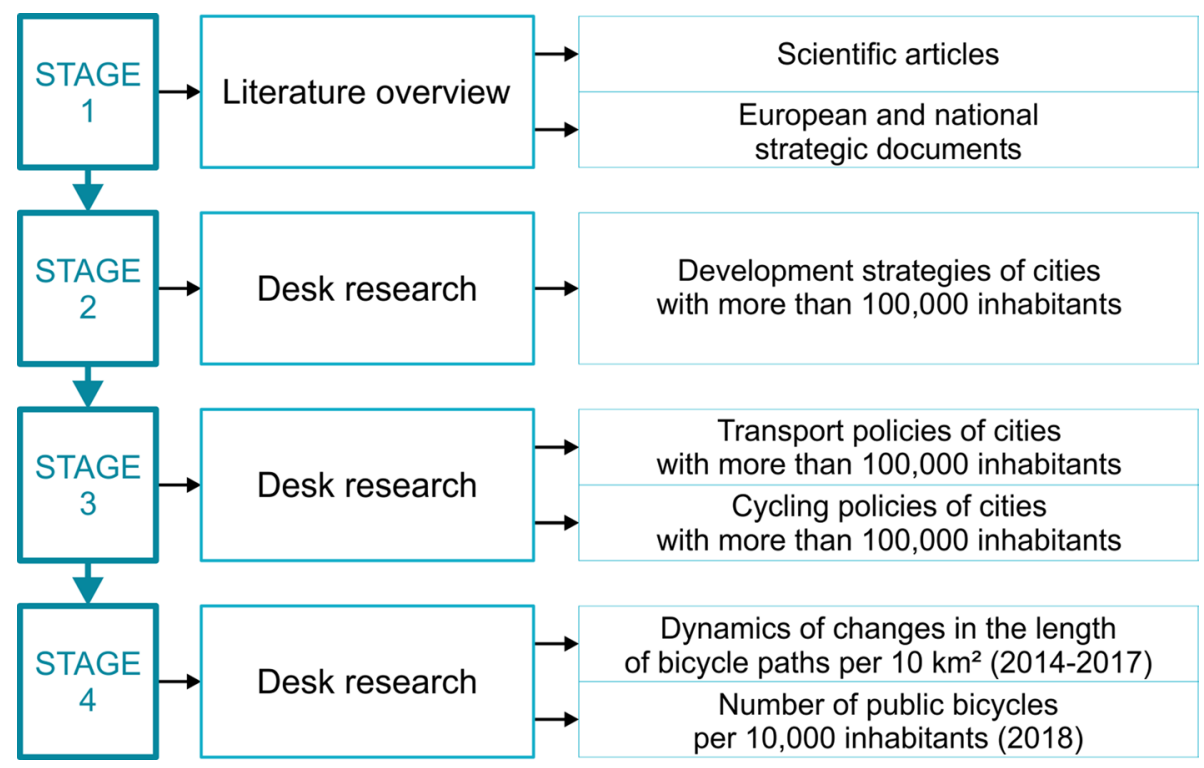

Fig. 2 Steps in the conduct of the study. Source: own elaboration 
- instruments for implementation - it was assessed whether the documents indicated both who prepared the strategy and who was to be responsible for the implementation of the assumed measures,

- diagnosis of the situation in the city-it was checked whether the authors of each study characterised at least in a general manner the baseline situation at the time of creating the document,

- diagnosis - statistical data - it was assessed whether, while diagnosing the situation in the city, the authors of the document used indicators describing the baseline cycling traffic in the city, e.g. whether data on the length of cycle paths were used and presented,

- identification of target groups-it was checked whether each strategy indicates the social groups that should be the recipients of the proposed solutions,

- infrastructural plans and actions-it was assessed whether the document contains indications as to possible measures for the development of cycling infrastructure,

- promotional plans and actions - it was assessed whether each document contains indications concerning possible promotional activities aimed to increase cycling traffic in the city,

- local design guidance - it was assessed whether each study includes indications of design solutions taking into account local conditions,

- reference to regional or national documents-we checked whether and to what extent the document refers to other strategic documents at higher levels

- monitoring and evaluation - it was assessed whether the authors of each strategy indicated tools for evaluating the implementation of the proposed measures,

- costs and sources of funding - it was checked whether the documents contained information about the costs of the activities and the possibility and method of financing them.

It should be noted that the second and third stages of the present study (analysis of the provisions of strategic documents) were carried out using the desk research method. Within the framework of these stages, the authors researched over 80 (not all of them were included in the study) strategic documents of 39 Polish cities (including urban development strategies and thematic strategies) with a population of at least 100,000 (see Table 1) (Szymańska 2013). It was assumed that it is in large cities that transport problems occur with the highest intensity and require the introduction of measures to promote cycling. A similar method was previously used in research on the development of cycling policies in cities (Adam et al. 2018). The method is also successfully used in other geographical studies, such as the analysis of the level of regional development (Percoco 2013; Makarewicz-Marcinkiewicz 2015) or the activities of Local Action Groups (Kola-Bezka 2020).

In the last, fourth stage of the study, the implementation of cycling policy assumptions was shown on the basis of statistical data concerning the dynamics of changes in the length of cycle paths (per $10 \mathrm{~km}^{2}$ in the years 2014-2017) and the number of public bicycles (per 10,000 inhabitants in 2018). Of course, these data do not give the full picture of cycling policy implementation, but they allow us to determine general trends in this respect. 
Table 1 Polish cities with population of at least 100,000 indicators

\begin{tabular}{|c|c|c|c|c|}
\hline City & A & B & $\mathrm{C}$ & $\mathrm{D}$ \\
\hline Warszawa & 517 & 3437 & 6.4 & 749.7 \\
\hline Kraków & 327 & 2359 & 5.5 & 639.4 \\
\hline Szczecin & 301 & 1339 & 2.1 & 554.5 \\
\hline Wrocław & 293 & 2188 & 7.0 & 689.9 \\
\hline Łódź & 293 & 2337 & 5.7 & 578.4 \\
\hline Zielona Góra & 277 & 504 & 0.8 & 572.6 \\
\hline Gdańsk & 262 & 1781 & 3.3 & 618.0 \\
\hline Poznań & 262 & 2048 & 3.8 & 725.1 \\
\hline Dąbrowa Górnicza & 189 & 637 & 2.4 & 598.1 \\
\hline Bydgoszcz & 176 & 1990 & 7.6 & 596.0 \\
\hline Katowice & 165 & 1789 & 3.3 & 734.6 \\
\hline Częstochowa & 160 & 1392 & 3.1 & 563.5 \\
\hline Opole & 149 & 861 & 2.0 & 688.0 \\
\hline Rybnik & 148 & 935 & 2.2 & 575.0 \\
\hline Lublin & 147 & 2303 & 5.4 & 557.2 \\
\hline Gdynia & 135 & 1823 & 2.2 & 601.9 \\
\hline Gliwice & 134 & 1343 & 3.2 & 667.7 \\
\hline Bielsko-Biała & 125 & 1375 & 1.7 & 650.9 \\
\hline Rzeszów & 120 & 1591 & 2.9 & 567.7 \\
\hline Toruń & 116 & 1746 & 3,4 & 535.0 \\
\hline Radom & 112 & 1905 & 4.9 & 513.1 \\
\hline Kielce & 110 & 1785 & 2.9 & 547.6 \\
\hline Białystok & 102 & 2913 & 4.8 & 452.5 \\
\hline Koszalin & 98 & 1091 & 2.0 & 523.8 \\
\hline Sosnowiec & 91 & 2219 & 5.0 & 551.5 \\
\hline Płock & 88 & 1363 & 3.0 & 651.7 \\
\hline Olsztyn & 88 & 1951 & 4.0 & 531.5 \\
\hline Gorzów Wielkopolski & 86 & 1446 & 4.7 & 588.8 \\
\hline Wałbrzych & 85 & 1329 & 2.2 & 313.9 \\
\hline Włocławek & 84 & 1314 & 1.5 & 513.2 \\
\hline Tychy & 82 & 1563 & 4.9 & 602.8 \\
\hline Zabrze & 80 & 2156 & 4.2 & 497.2 \\
\hline Elbląg & 80 & 1505 & 2.4 & 496.3 \\
\hline Ruda Śląska & 78 & 1775 & 4.1 & 503.9 \\
\hline Tarnów & 72 & 1507 & 1.8 & 505.2 \\
\hline Bytom & 69 & 2402 & 5.0 & 476.5 \\
\hline Kalisz & 69 & 1455 & 2.4 & 684.5 \\
\hline Legnica & 56 & 1772 & 4.5 & 528.1 \\
\hline Chorzów & 33 & 3262 & 20.9 & 449.2 \\
\hline
\end{tabular}

Legend: A-area in $\mathrm{km}^{2}$ (2018), B-population per $1 \mathrm{~km}^{2}$ (2018), $\mathrm{C}$ - share of parks, lawns and estate green areas in the total area (2018), D-number of cars per 1000 inhabitants (2018)

Source: own elaboration based on data from the Central Statistical Office of Poland (BDL GUS) 


\section{Results of the search of general urban development strategies in the context of cycling policy provisions}

As mentioned earlier, in the second stage of the work, strategic documents of a general nature — urban development strategies (39)—were analysed in order to assess to what extent and in what context they contained provisions related to cycling. Five clearly delineated areas were identified on the basis of the document search: transport, communication and mobility; tourism, recreation and sports; health; safety; quality of life and spatial order (Fig. 3).

In order to assess which area recorded the largest number of provisions, the authors analysed their occurrence in particular strategies. For each of the cities, the number of cycling issues in the strategy and then their percentage share in particular areas was calculated (structural bar chart). In each of the cities, a different number of provisions in the strategies constitutes $100 \%$ (from 1 to over 70).

The collected data (Fig. 3) show that the issue of cycling is an element of the general development strategy in 37 out of 39 examined cities (except for Łódź and Sosnowiec). In each of them, cycling is mentioned in the context of transport. The area of tourism, recreation and sports includes cycling in 27 cities, health in 3 cities, safety in 5 cities and quality of life and spatial order in 16 cities. In some cities, cycling-related provisions are found only in the areas of transport, communication and mobility (Gdańsk, Olsztyn, Opole and Elblag). It is worth mentioning that a high percentage of provisions related to tourism, recreation and sports was recorded in the policies of Dąbrowa Górnicza, Włocławek, Legnica, Szczecin and Płock. The links with the health policy of the city were defined in the strategies of Bielsko-Biała, Wałbrzych and Koszalin-in these strategies the development of cycling was treated as an opportunity to improve the health of the inhabitants of these cities. The problem of cyclist safety is more broadly addressed in five strategies, including the most visible one in the Kalisz development strategy. The provisions related to the quality of life and spatial order were most broadly described in the strategies of Gorzów Wielkopolski and Kielce. In the documents of these two cities, cycling infrastructure was treated as an element of planning a friendly urban space with the possibility of using cycling transport as a determinant of the high quality of life in the city. The widest scope, covering the most thematic areas, was recorded in Kalisz, Wałbrzych, Rzeszów and Gdynia. In the development strategies of these cities, the issues related to cycling were considered in four different thematic areas.

To conclude, at the general level of strategic planning in Polish cities, cycling policy is present in five clearly marked areas. However, transport plays an important role in each of the documents, which indicates a great potential for the development of cycling in the daily mobility of city-dwellers.

\section{Results of the search of thematic documents in the context of cycling policy provisions}

The second stage of the review of strategic documents referred to the provisions concerning cycling in urban transport policies and cycling policies, i.e. thematic documents. As a result of a thorough search of these documents, it was found that thematic documents were adopted in 20 cities (in some of them more than one such study was diagnosed). Moreover, 


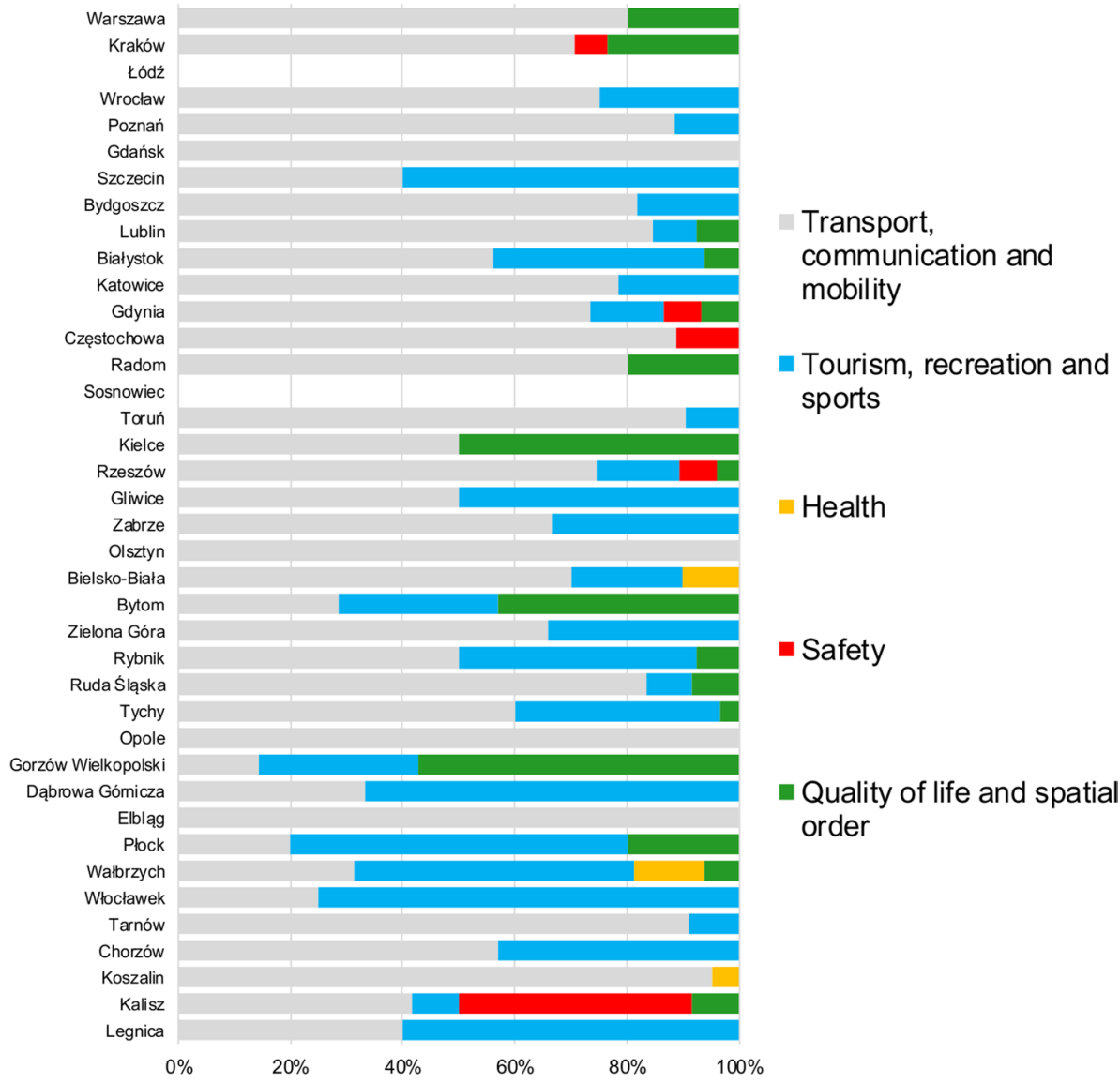

Fig. 3 Structure of provisions concerning cycling in particular areas in urban development strategies. Source: own elaboration based on Częstochowa 2025. City development strategy, Białystok City Development Strategy for 2011-2020 plus, Bielsko-Biała Development Strategy until 2020, Bydgoszcz Development Strategy until 2030, Bytom City Development Strategy 2020+, Chorzów Development Strategy until 2030, City Development Strategy-Olsztyn 2020, City Development Strategy - Zabrze 2030, City Development Strategy: Dąbrowa Górnicza 2022—update, Development Strategy of the City of Rzeszów until 2025, Elbląg Development Strategy 2020+, Gdańsk 2030 Plus - City Development Strategy, Gdynia City Development Strategy 2030, I want to live here. Kraków 2030. Kraków Development Strategy, Kalisz City Development Strategy for the Years 2014-2024, Katowice City Development Strategy 2030, Kielce City Development Strategy for the years 2007-2020, Koszalin Development Strategy, Legnica - Development Strategy 2015-2020 Plus, Lublin Development Strategy for 2013-2020, Radom City Development Strategy for 2008-2020, Opole Development Strategy 2012-2020, Poznań City Development Strategy 2020+, Ruda Śląska City Development Strategy for 2014-2030, Czestochowa Development Strategy 2030+, Strategy for integrated development of Łódź 2020+, Strategy of Integrated and Sustainable Development of the City of Gliwice until 2022, Strategy of Integrated Development of the City of Rybnik until 2020, Strategy Warsaw 2030, Sustainable Development Strategy of Gorzów Wielkopolski. for the years 2010-2020, Sustainable Development Strategy of the City of Płock until 2030, Szczecin Development Strategy 2025, Tarnów City Development Strategy 2020, Torun City Development Strategy to 2020 with a development perspective until 2028, Tychy City Development Strategy 2020+, Walbrzych Sustainable Development Strategy until 2020, Włocławek City Development Strategy 2020 +, Wrocław Strategy 2030 
the provisions related to cycling policy were found to refer mainly to the development of the cycle paths network. However, other solutions were also proposed, such as parking racks for bicycles and the introduction of public bicycles. This part of the study analyses whether the thematic documents are consistent in terms of content with the recommendations of the European Commission concerning the creation of cycling policy (Table 2).

The data collected in Table 2 show that urban cycling policies (thematic documents) differ in content (cf. the twelve European Commission guidelines). The provisions were closest to the EC guidelines in the Rybnik cycling policy and the furthest in Łódź, which may be caused by the imprecise and vague provisions in the documents in the latter city. Infrastructural plans and actions describing the general framework and directions of development of cycle paths (Table 2-VII) were the most frequently appearing element. In most of the analysed documents, the indications concerning the development of cycling infrastructure were in fact the most important item. In the vast majority of cycling policies, the objectives of cycling policy were identified (Table 2-II) and a general diagnosis of cycling traffic in the city was described (Table 2-IV). None of the analysed documents indicated the target groups (Table 2-VI) to which the cycling policy provisions were addressed, which may result from an attempt to make cycling accessible to all inhabitants and visitors of the cities.

Attention should be drawn to the advantage of provisions concerning infrastructure (Table 2-VII) over promotional activities (Table 2-VIII). Imbalances between these two elements may be critical for the effectiveness of the activities - the lack of appropriate promotion may jeopardise the achievement of the objective of increasing cycling traffic in the cities. The selected documents also show a lack of an in-depth diagnosis of the condition of cycling infrastructure expressed by statistical data, e.g. an analysis of the actions taken so far and information on the condition of cycling infrastructure in the city.

\section{Implementation of cycling policy provisions in the context of changes taking place in cycling infrastructure}

In order to assess whether the provisions of strategic documents (general and thematic) concerning cycling policy are implemented by particular cities, the authors analysed statistical data showing the development of the cycle paths network and the availability of bicycles in bicycle-sharing systems. Due to the fact that the expansion of cycling infrastructure is a postulate of the vast majority of cycling policies, indicators concerning its development were selected for the assessment of the measures carried out. The authors are aware that the analysis does not constitute a full assessment of the implementation of strategic provisions; however, it allowed them to partially assess whether the studied cities carry out any activities for the development of cycling traffic. Table 3 analyses the number of public bicycles per 10,000 inhabitants and the change in the value of indicators describing the length of bicycle paths per $10 \mathrm{~km}^{2}$.

The data collected in Table 3 indicate that the vast majority of cities in the period of 2014-2017 recorded an increase in the value of the indicator concerning the length of bicycle paths per $10 \mathrm{~km}^{2}$. In 2014, the highest values of the ratio were recorded in Białystok (10.38) and Rzeszów (10.31), similarly in 2017-11.52 and 12.54, respectively, while the lowest values in 2014 in Dąbrowa Górnicza, Rybnik and Zielona Góra. In 2017, the lowest value of the indicator concerning the length of bicycle paths per $10 \mathrm{~km}^{2}$ was recorded in Dąbrowa Górnicza and Rybnik. In order to show which of the 


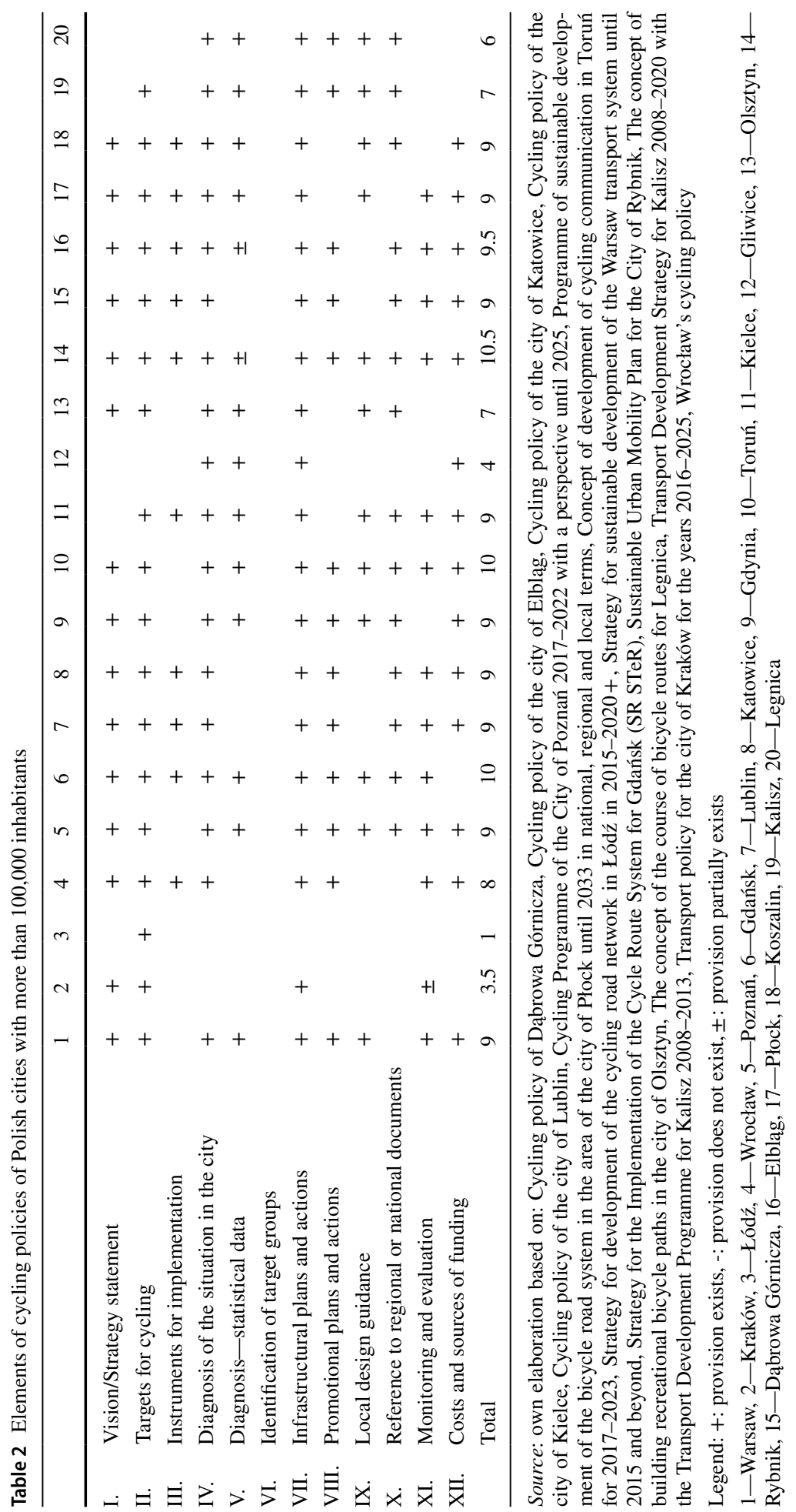


Table 3 Number of public bicycles per 10,000 inhabitants in 2018, length of bicycle paths per $10 \mathrm{~km}^{2}$ in cities with more than 100,000 inhabitants in Poland in the years 2014-2017

\begin{tabular}{|c|c|c|c|c|}
\hline City & A & B & $\mathrm{C}$ & $\mathrm{D}$ \\
\hline Warsaw & 30.14 & 7.98 & 10.40 & $130 \mathrm{D} \%$ \\
\hline Kraków & 19.55 & 4.71 & 6.75 & $143 \mathrm{D} \%$ \\
\hline Łódź & 22.94 & 3.96 & 5.29 & $134 \mathrm{D} \%$ \\
\hline Wrocław & 12.84 & 7.36 & 8.53 & $116 \mathrm{D} \%$ \\
\hline Poznań & 22.78 & 5.11 & 6.68 & $131 \mathrm{D} \%$ \\
\hline Gdańsk & 0.00 & 6.10 & 6.66 & $109 \mathrm{D} \%$ \\
\hline Szczecin & 18.37 & 3.66 & 4.07 & $111 \mathrm{D} \%$ \\
\hline Bydgoszcz & 15.89 & 4.39 & 4.83 & $110 \mathrm{D} \%$ \\
\hline Lublin & 25.05 & 7.43 & 9.83 & $132 \mathrm{D} \%$ \\
\hline Białystok & 20.65 & 10.38 & 11.52 & $111 \mathrm{D} \%$ \\
\hline Katowice & 15.26 & 3.53 & 4.50 & $128 \mathrm{D} \%$ \\
\hline Gdynia & 0.00 & 3.93 & 4.38 & $111 \mathrm{D} \%$ \\
\hline Częstochowa & 8.25 & 3.19 & 4.32 & $135 \mathrm{D} \%$ \\
\hline Radom & 12.58 & 3.18 & 4.64 & $146 \mathrm{D} \%$ \\
\hline Sosnowiec & 6.37 & 1.24 & 2.54 & $204 \mathrm{D} \%$ \\
\hline Toruń & 0.00 & 7.26 & 9.51 & $131 \mathrm{D} \%$ \\
\hline Kielce & 0.00 & 2.55 & 4.48 & $175 \mathrm{D} \%$ \\
\hline Rzeszów & 5.27 & 10.31 & 12.54 & $122 \mathrm{D} \%$ \\
\hline Gliwice & 8.27 & 2.18 & 2.77 & $127 \mathrm{D} \%$ \\
\hline Zabrze & 2.87 & 1.97 & 2.94 & $149 \mathrm{D} \%$ \\
\hline Olsztyn & 6.36 & 6.71 & 8.60 & $128 \mathrm{D} \%$ \\
\hline Bielsko-Biała & 0.00 & 2.09 & 2.65 & $127 \mathrm{D} \%$ \\
\hline Bytom & 0.00 & 1.35 & 4.16 & $307 \mathrm{D} \%$ \\
\hline Zielona Góra & 25.75 & 0.96 & 2.37 & $247 \mathrm{D} \%$ \\
\hline Rybnik & 5.75 & 0.80 & 1.38 & $174 \mathrm{D} \%$ \\
\hline Ruda Śląska & 0.00 & 1.81 & 3.29 & $182 \mathrm{D} \%$ \\
\hline Tychy & 4.68 & 5.17 & 5.90 & $114 \mathrm{D} \%$ \\
\hline Opole & 15.45 & 6.13 & 5.05 & $82 \mathrm{D} \%$ \\
\hline Gorzów Wlkp. & 0.00 & 4.37 & 5.39 & $123 \mathrm{D} \%$ \\
\hline Dąbrowa Górnicza & 0.00 & 0.32 & 0.40 & $125 \mathrm{D} \%$ \\
\hline Elbląg & 0.00 & 4.76 & 5.52 & $116 \mathrm{D} \%$ \\
\hline
\end{tabular}


Table 3 (continued)

\begin{tabular}{lcccc} 
Płock & 20.78 & 3.54 & 5.17 & $146 \mathrm{D}(\%)$ \\
\hline Wałbrzych & 0.00 & 1.52 & 2.92 & $191 \mathrm{D}(\%)$ \\
\hline Włocławek & 0.00 & 5.21 & 6.99 & $134 \mathrm{D}(\%)$ \\
\hline Tarnów & 10.03 & 7.60 & 9.26 & $122 \mathrm{D}(\%)$ \\
\hline Chorzów & 13.76 & 4.99 & 5.66 & $113 \mathrm{D}(\%)$ \\
\hline Koszalin & 9.29 & 4.70 & 7.27 & $155 \mathrm{D}(\%)$ \\
\hline Kalisz & 27.85 & 5.36 & 6.31 & $118 \mathrm{D}(\%)$ \\
\hline Legnica & 10.77 & 5.12 & 5.88 & $115 \mathrm{D}(\%)$
\end{tabular}

Legend: A - Number of public bicycles per 10,000 inhabitants (2018), B - length of bicycle paths per $10 \mathrm{~km}^{2}$ (2014), C - length of bicycle paths per $10 \mathrm{~km}^{2}$ (2017), D - dynamics of changes in the length of bicycle paths per $10 \mathrm{~km}^{2}(2014=100 \mathrm{D}(\%))$

Colour explanations:

Number of public bicycles per 10,000 inhabitants:

\begin{tabular}{|l|l|l|l|l|}
\hline$<10$ & $10-15$ & $15-20$ & $20-25$ & $>25$ \\
\hline
\end{tabular}

Length of bicycle paths per $10 \mathrm{~km}^{2}$ :

\begin{tabular}{|c|c|c|c|}
\hline$<1$ & $1-5$ & $5-10$ & $>10$ \\
\hline
\end{tabular}

source: own elaboration based on data from the Central Statistical Office of Poland (BDL

GUS) and Kwiatkowski, 2018a

cities saw the biggest development of the cycle paths network in the analysed period, the dynamics of change in the value of the analysed indicator was calculated. The data collected in Table 2 show how the length of cycle paths per $10 \mathrm{~km}^{2}$ changed in 39 largest cities in Poland between 2014 and 2017. The biggest growth took place in Bytom, Zielona Góra and Sosnowiec. It is worth noting that significant favourable changes of more than a doubling or almost a doubling of the length of cycle paths took place in industrial cities: Bytom, Sosnowiec, Ruda Śląska, Rybnik (cf. Table 2). In these cities, the problems of environmental pollution are particularly visible; therefore, the scale of their activities for the development of cycling should be assessed positively. It is worth mentioning that in addition to own funds, more and more local authorities are using European Union funds to solve the transport problem, which undoubtedly also contributes to the development of cycling infrastructure.

While in 2014 there were three cities in the range covering the lowest values of the indicator in question-Zielona Góra, Rybnik and Dąbrowa Górnicza_in 2017 only the last of the mentioned cities remained in that range (cf. Table 2). The number of cities belonging to the range with the highest value of the analysed indicator concerning the length of cycle paths also increased from two to three. From among 39 cities, 10 jumped to a higher range, while the remaining ones remained in the same range. 
Public bicycle systems which enable self-service renting and return of bicycles in urban space are a crucial element of the cycling infrastructure developed within the framework of the development strategy. The study assessed the availability of bicycles in cities by analysing the number of public bicycles per 10,000 inhabitants (Table 3). In the group of 39 cities covered by the analysis, in 2018 a self-service bicycle rental system operated in 27 . The highest number of public bicycles per 10,000 inhabitants was recorded in Warsaw where it amounted to 30.14, in Kalisz (27.85) and Zielona Góra (25.75). A relatively small number of public bicycles per 10,000 inhabitants, despite the development of the cycle paths network, was available in Tychy and Zabrze: 4.68 and 2.87 , respectively.

To sum up, the analysis of cycling policy of Polish cities indicates that the vast majority of 39 cities in Poland have provisions related to cycling in the general development strategy. They are expressed to varying degrees in the form of postulates assigned to many areas of urban life, most often transport and recreation. Some cities have decided to broaden the scope of planned strategic actions by adopting thematic documents concerning transport policy or, more specifically, cycling policy. The analysed thematic documents emphasise the importance of cycling for the development of sustainable urban mobility (Cycling Policy of the City of Kielce). As the present study shows, the aim of cycling policies in Poland (at the national, regional and local level) is primarily to improve the quality of transport and make it less burdensome for the environment, the urban economy and society (Wrocław Cycling Policy). The authors of these documents also notice a growing trend in bicycle use and recommend carrying out activities aimed at its development (Cycling Programme of the City of Poznań 2017-2022 with a Perspective until 2025). Cycling policies of Polish cities also point to threats to the safety of cyclists in urban traffic (Cycling Policy of the City of Kielce). One of the numerous tasks set out in these documents is to highlight the role of cycling in combination with public transport as an alternative to car traffic in cities (Sustainable Urban Mobility Plan for the City of Rybnik). The conducted search shows that the adoption of general and thematic strategies allows and will allow for more effective implementation of pro-cycling activities in the city (Concept of Cycling Development in Toruń for 2017-2023).

Cycling policies of Polish cities recorded in both general and thematic strategic documents draw particular attention to the need to increase the share of cycling in urban transport, to improve the cohesion and safety of cycle paths and to integrate cycling with public transport. This indicates that the urban cycling policies are in line with national and European documents, although they are not always complete.

\section{Discussion}

The cycling policy problem is a challenge in the different parts of the world. Therefore, the ways to deal with the challenge are various and depend on region and the development of cycling culture. The countries of Western Europe are the most effective in the field of cycling policy. The effectiveness of pro-cycling activities in the Netherlands, Denmark and Germany results from appropriately prepared, safe infrastructure, ensuring connections with other forms of public transport, and promotional activities (Agervig Carstensen and Ebert 2012; Buehler et al. 2017b; Pucher and Buehler 2008). One of the best examples of urban cycling policy is the Danish capital, Copenhagen. (Gossling 2013; Gossling and Choi 2015). In Denmark, cycling is not only a means of transport, but also a part of multimodal journeys to public transport nodes (Olafsson et al. 2016). Research carried out in 
Denmark also shows that the choice of cycling in transport is no longer made exclusively by the inhabitants of large cities-more and more often the inhabitants of small towns and villages are opting for that mode of transport (Olafsson et al. 2016). Much earlier experiences in German cities also show that a properly implemented cycling policy and a serious approach to cycling can effectively increase urban cycling (Pucher 1997, 1998; Pucher and Dijkstra 2000). However, research from German cities has also shown how important it is to target cycling policy measures appropriately according to the cycling destinations of the citizens (Goetzke and Rave 2011). Similar postulates are included in sustainable urban mobility plans in Spain, where the solutions for cyclists most often include infrastructural measures, including those aimed at city centres. An equally important role in these studies is assigned to promotional activities. Recommendations contained in the discussed strategies suggest that bicycle sharing may be a useful tool in this respect (Mozos-Blanco et al. 2018). The results of research conducted by Perez et al. (2017) in Barcelona confirm that the implementation of cycling policy consisting in the creation of safe infrastructure for cyclists is conducive to the growth of cycling traffic and consequently to the increase in the inhabitants' physical activity. Ensuring appropriate conditions for cycling development is also a subject of cycling policies in the largest North American (Pucher et al. 2011a), Asian (Aslam et al. 2018; Bakker et al. 2018) and Australian cities (Pucher et al. 2011b). The implementation of cycling policies in North American cities has contributed to a significant increase in the number of cyclists (Pucher et al. 2011a). The review of cycling policies of Australian cities carried out by Pucher et al. 2011b shows a number of actions taken in favour of cycling, while diagnosing the need to pay attention to the coherence of cycling infrastructure within metropolitan areas. The need for introducing urban cycling policies was also diagnosed in Asian developing countries, with the researchers highlighting the potential of this form of transport (Aslam et al. 2018).

Poland, as a country of Central and Eastern Europe, is characterised by a lower degree of development of cycling culture than its Western European counterparts. However, the present study has shown that Polish cities see the role of cycling primarily within urban transport, which clearly shows the need to invest in this form of mobility and promote it in that context. In the analysed development strategies of all the studied cities, cycling is most often addressed in the area of transport and is not treated as a means of recreation only. This shows that the biggest Polish cities notice the potential in cycling as a sustainable alternative in urban transport. This aspect is particularly emphasised in the policies of the largest of the studied cities (Warsaw, Kraków, Poznań, Gdańsk). The problems of infrastructure-mainly the cohesion of the cycle paths network, as well as the safety of cyclists, similarly as in cycling policies worldwide, is also the main subject of cycling issues presented in the strategic documents of Polish cities, which shows that the problem is of a global nature.

\section{Summary}

Cycling is found in strategic documents at different levels of urban and regional development planning. Owing to this, the provisions in favour of cycling not only become a promise of action to the inhabitants, but they also indicate the directions in which this form of urban mobility can develop. To a large extent cycling policy in the strategies of Polish cities shows coherence with European and national documents. This allows for a systemic approach to solving the diagnosed problems of cycling traffic. While the 
message is generally consistent, and in most of the analysed cases it deals with the same problems and brings forth similar postulates, the lack of a uniform structure means that certain elements are not articulated in such a way as to ensure that they are implemented. Despite the existing European guidelines (cf. Table 1) related to the shaping of urban cycling policies, Poland has not yet developed a model according to which those documents can be prepared.

Cities decide to carry out activities for cyclists because they are aware of the fact that it has a positive impact on their image. The conducted analysis also indicates that the presence and quality of provisions in a cycling policy does not always correspond to the real activities of local governments in this area. This does not mean, however, that individual local governments do not achieve the assumed objectives. Despite the differences in the form and content of the provisions shown and the observed incompleteness of the analysed strategies, the study has shown that measures for the development of cycling infrastructure are carried out in all analysed cities. A comparison between the provisions and selected infrastructural investments of the cities shows that the development of cycle paths and accessibility of public bicycle systems is also carried out by local governments of cities where these provisions do not appear in the form of separate cycling policies.

Local governments of the vast majority of Polish cities have already made a significant step towards the development of cycling. This is confirmed by the presence of appropriate provisions in the strategies but also by the actions taken for the development of cycling infrastructure. On the other hand, it should be remembered that the scale of actions taken so far and the plans presented in the strategic documents do not yet fully solve transport problems in Polish cities. The analysis points to the need to supplement and develop individual provisions of urban transport strategies. The intensive development of cycling in cities gives the authorities a chance to increase the scope of proposed actions for the benefit of cycling in subsequent periods of planning urban development strategies and transport policies.

Acknowledgements The authors would like to thank the anonymous reviewers for their comments that helped us improve our article.

Author's contribution 1. 65\% contribution: study conception, literature search and review, data collection, analysis and interpretation of data, manuscript preparation. $2.35 \%$ contribution: study conception, analysis and interpretation of data, manuscript preparation.

Open Access This article is licensed under a Creative Commons Attribution 4.0 International License, which permits use, sharing, adaptation, distribution and reproduction in any medium or format, as long as you give appropriate credit to the original author(s) and the source, provide a link to the Creative Commons licence, and indicate if changes were made. The images or other third party material in this article are included in the article's Creative Commons licence, unless indicated otherwise in a credit line to the material. If material is not included in the article's Creative Commons licence and your intended use is not permitted by statutory regulation or exceeds the permitted use, you will need to obtain permission directly from the copyright holder. To view a copy of this licence, visit http://creativecommons.org/licenses/by/4.0/.

\section{References}

Adam, L., Jones, T., \& te Brommelstroet, M. (2018). Planning for cycling in the dispersed city: Establishing a hierarchy of effectiveness of municipal cycling policies. Transportation. https://doi.org/10.1007/ s11116-018-9878-3. 
Agervig Carstensen, T., \& Ebert, A. K. (2012). Cycling Cultures in Northern Europe: From 'Golden Age' to 'Renaissance', Parkin, J. (Ed.), Cycling and Sustainability, Emerald: Bingley, 23-58, ISBN 978-1-78052-298-2.

Aldred, R., \& Dales, J. (2017). Diversifying and normalizing cycling in London, UK: An Exploratory study on the influence of infrastructure. Journal of Transport \& Health, 4, 348-362. https://doi. org/10.1016/j.jth.2016.11.002.

Aldred, R., Watson, T., Lovelace, R., \& Woodcock, J. (2017). Barriers to investing in cycling: Stakeholder views from England. Transportation Research Part A: Policy and Practice. https://doi.org/10.1016/j. tra.2017.11.003. (in Press).

Arsenio, E., Martens, K., \& Di Ciommo, F. (2016). Sustainable urban mobility plans: Bridging climate change and equity targets? Research in Transportation Economics, 55, 30-39. https://doi. org/10.1016/j.retrec.2016.04.008.

Aslam, S. A. B., Masoumi, H. E., Asim, M., \& Anwer, I. (2018). Cyclability in Lahore, Pakistan: Looking into potential for greener urban traveling. Tema Journal of Land Use, Mobility and Environment, 11(3), 323-343. https://doi.org/10.6092/1970-9870/5806.

Bakker, S., Guillen, M. D., Nanthachatchavankul, P., Zuidgeest, M., Pardo, C. F., \& van Maarseveen, M. (2018). Hot or not? The role of cycling in ASEAN megacities: Case studies of Bangkok and Manila. International Journal of Sustainable Transport, 12(6), 416-431. https://doi. org/10.1080/15568318.2017.1384522.

Bednarek, S., Latacz, A., \& Piwowarczyk, M. (2009). Częstochowa 2025. City development strategy. Częstochowa Municipal Office, Częstochowa City Development Strategy Office.

Białystok City Development Strategy for 2011-2020 plus. Retrieved January 08, 2019, from https:// www.bialystok.pl/resource/file/download-file/id.452. Resource document.

Bielsko-Biała Development Strategy until 2020. Retrieved January 08, 2019, fromhttps://bielsko-biala .pl/uploads/pub/pages/page_712/text_images/XX_496_2012.pdf. Resource document.

Bloyce, D., \& White, C. (2018). When transport policy becomes health policy: A documentary analysis of active travel policy in England. Transport Policy, 72, 13-23. https://doi.org/10.1016/j.tranp ol.2018.09.012.

Buehler, R., \& Dill, J. (2015). Bikeway networks: A review of effects on cycling. Transport Reviews, 36(1), 9-27. https://doi.org/10.1018/01441647.2015.1069908.

Buehler, R., Pucher, J., \& Altshuler, A. (2017a). Vienna's path to sustainable transport. International Journal of Sustainable Transportation, 11(4), 257-271. https://doi.org/10.1080/15568 318.2016.1251997.

Buehler, R., Pucher, J., Gerike, R., \& Gotschi, T. (2017b). Reducing car dependence in the heart of Europe: Lessons from Germany, Austria, and Switzerland. Transport Reviews, 37(1), 4-28. https:// doi.org/10.1080/01441647.2016.1177799.

Butterworth, E., \& Pojani, D. (2018). Why Isn't Australia a cycling Mecca? European Transport-Transporti Europei, 69(4), ISSN 1825-3997.

Bydgoszcz Development Strategy until 2030. Retrieved January 08, 2019, from https://www.bydgoszcz. pl/fileadmin/multimedia/rozwoj/Strategia/STRAT_2030_folder_PL.pdf. Resource document.

Bytom City Development Strategy 2020+. Retrieved January 08, 2019, from https://www.bytom.pl/ plik/1902,strategia-bytom-2020-pdf. Resource document.

Chorzów Development Strategy until 2030. Retrieved January 08, 2019, from https://bip.chorzow.eu/ add_www/file/strategia_rozwoju_chorzowa_do_2030.pdf. Resource document.

City Development Strategy - Zabrze 2030. Retrieved January 08, 2019, from https://miastozabrze.pl/ miasto/dokumenty-strategiczne/strategia-rozwoju-miasta-zabrze-2030/. Resource document.

City Development Strategy - Olsztyn. (2020). Retrieved January 08, 2019, from https://www.olsztyn.eu/ fileadmin/katalogi_wydzialowe/gospodarka/strategia/katalogi/Strategia_Olsztyn_polska.pdf. Resource document.

City Development Strategy: Dąbrowa Górnicza 2022 - update. Retrieved January 08, 2019, from https:// www.bip.dabrowa-gornicza.pl/api/download/file?id=86336. Resource document.

Cycling policy of Dąbrowa Górnicza. Retrieved January 08, 2019, from https://www.bip.dabrowa-gorni cza.pl/api/download/file?id=69461. Resource document.

Cycling policy of the city of Elblagg. Retrieved January 08, 2019, from https://um-elblag.samorzady.pl/ zalacznik/id/19335. Resource document.

Cycling policy of the city of Katowice. Retrieved January 08, 2019, from https://katowice.eu//rowerem/ PublishingImages/rowerem/dokumenty-strategiczne/Polityka\%20Rowerowa\%20Miasta\%20Kat owice.pdf. Resource document. 
Cycling policy of the city of Kielce. Retrieved January 08, 2019, from https://um.kielce.pl/gfx/kielce2/ userfiles/files/srodowisko/etzt2009/polityka_rowerowa_miasta_kielce_pelna_wersja.pdf. Resource document.

Cycling policy of the city of Lublin. Retrieved January 08, 2019, from https://docplayer.pl/37947 170-Zalacznik-do-uchwaly-nr-rady-miasta-lublin-z-dnia-polityka-rowerowa-miasta-lublin.html. Resource document.

Cycling Programme of the City of Poznań 2017-2022 with a perspective until 2025. Retrieved January 08, 2019, from https://bip.poznan.pl/public/bip/attachments.att?co=show\&instance=1001\&paren $\mathrm{t}=23486 \&$ lang $=$ pl\&id $=51827$. Resource document.

Development Strategy of the City of Rzeszów until 2025. Retrieved January 08, 2019, from https://s.bip. erzeszow.pl/file/63908/Strategia+Rozwoju+Miasta+Rzeszowa+cz.+I.pdf. Resource document.

Elbląg Development Strategy 2020 +. Retrieved January 08, 2019, from https:/elblag.eu/images/stori es/9_strategia/pdf/Strategia.pdf. Resource document.

EU Cycling Strategy. Recommendations for Delivering Green Growth and an Effective Mobility System in 2030 (2017). Retrieved January 08, 2019, from https://ecf.com/sites/ecf.com/files/EUCS_full_ doc_small_file.pdf. European Cyclists' Federation (ECF) asbl. Resource document.

European Union Green Paper - Towards a new culture for urban mobility. Retrieved January 08, 2019, from https://eur-lex.europa.eu/legal-content/EN/ALL/?uri=CELEX:52007DC0551. Resource document.

European Union White Paper on Transport. Retrieved January 08, 2019, from https://ec.europa.eu/trans port/sites/transport/files/themes/strategies/doc/2011_white_paper/white-paper-illustrated-broch ure_en.pdf. Resource document.

Fernandez-Heredia, A., Monzon, A., \& Jara-Diaz, S. (2014). Understanding cyclists' perceptions, keys for a successful bicycle promotion. Transportation Research Part A: Policy and Practice, 63, 1-11. https://doi.org/10.1016/j.tra.2014.02.013.

Gaffron, P. (2003). The implementation of walking and cycling policies in British local authorities. Transport Policy, 10(3), 235-244. https://doi.org/10.1016/S0967-070X(03)00024-6.

Gdańsk 2030 Plus - City Development Strategy, Retrieved January 08, 2019, from https://www.gdans k.pl/download/2015-01/58301.pdf. Resource document.

Gdynia City Development Strategy 2030. Retrieved January 08, 2019, from https://2030.gdynia.pl/cms/ fck/uploaded/strategia\%20rozwoju\%20miasta\%20gdyni\%202030_folder.pdf. Resource document.

Goetzke, F., \& Rave, T. (2011). Bicycle use in Germany: Explaining differences between municipalities with social network effects. Urban Studies, 48(2), 427-437. https://doi.org/10.1177/0042098009 360681 .

Gossling, S. (2013). Urban transport transitions: Copenhagen, city of cyclists. Journal of Transport Geography, 33, 196-206. https://doi.org/10.1016/j.jtrangeo.2013.10.013.

Gossling, S., \& Choi, A. S. (2015). Transport transitions in copenhagen: Comparing the cost of cars and bicycles. Ecological Economics, 113, 106-113. https://doi.org/10.1016/j.ecolecon.2015.03.006.

I want to live here. Kraków 2030. Kraków Development Strategy. Retrieved January 08, 2019, from https ://www.bip.krakow.pl/zalaczniki/dokumenty/n/213730/karta. Resource document.

Iwińska, K., Blicharska, M., Pierotti, L., Tainio, M., \& de Nazelle, A. (2018). Cycling in Warsaw, Poland-perceived enablers and barriers according to cyclsts and non-cyclists. Transportation Research Part A: Policy and Practice, 113, 291-301. https://doi.org/10.1016/j.tra.2018.04.014.

Jensen, A. (2013). Controlling mobility, performing borderwork: Cycle mobility in Copenhagen and the multiplication of boundaries. Journal of Transport Geography, 30, 220-226. https://doi. org/10.1016/j.jtrangeo.2013.02.009.

Johansson, C., Lovenheim, B., Schantz, P., Wahlgren, L., Almstrom, P., Markstedt, A., et al. (2017). Impacts on air pollution and health by changing commuting from car to bicycle. Science of the Total Environment, 584-585, 55-63. https://doi.org/10.1016/j.scitotenv.2017.01.145.

Jordi-Sanchez, M. (2018). Social perceptions of the promotion of cycling as a mode of transport for children in Andalusia (Spain). Journal of Transport Geography, 72, 86-93. https://doi.org/10.1016/j. jtrangeo.2018.08.014.

Kalisz City Development Strategy for the Years 2014-2024. Retrieved January 08, 2019, from https ://www.kalisz.pl/storage/file/core_files/2018/5/25/30ef101646bc92ea5cb02b55fcfcc944/strategia_ rozwoju_miasta_kalisza_na_lata_2014-2024.pdf. Resource document.

Katowice City Development Strategy 2030. Retrieved January 08, 2019, from https://bip.katowice.eu/ Lists/Dokumenty/Attachments/95384/1450771333.pdf. Resource document.

Kielce City Development Strategy for the years 2007-2020. Updated. Retrieved January 08, 2019, from https://um.kielce.pl/gfx/kielce2/userfiles/files/pliki/strategia-rozwoju-miasta-kielce-aktualizac ja-15092016.pdf. 
Kola-Bezka, M. (2020). Are LAGs contributing to solving social exclusion problems? The case of Kujawsko-Pomorskie Voivodship. Bulletin of Geography. Socio-economic Series, 48, 35-45. https ://doi.org/10.2478/bog-2020-0012.

Koszalin Development Strategy. Retrieved January 08, 2019, from https://bip.koszalin.pl/attachments/ download/41893. Resource document.

Kwiatkowski, M. A. (2018a). Bike-sharing-boom-rozwój nowych form zrównoważonego transportu w Polsce na przykładzie roweru publicznego. Prace Komisji Geografi Komunikacji PTG. https://doi. org/10.4467/2543859xpkg.18.017.10142.

Kwiatkowski, M. A. (2018b). Urban cycling as an indicator of socio-economic innovation and sustainable transport. Quaestiones Geographicae, 37(4), 23-32. https://doi.org/10.2478/quage o-2018-0039.

Legnica - Development Strategy 2015-2020 Plus. Retrieved January 08, 2019, from https://um.bip.legni ca.eu/download/107/27314/StrategiarozwojuMiastaLegnicy2015-2020PLUSnowewskaznikizaut opoprawka.docx. Resource document.

López, O. S., \& Montero, S. (2018). Expert-citizens: Producing and contesting sustainable mobility policy in Mexican cities. Journal of Transport Geography, 67, 137-144. https://doi.org/10.1016/j. jtrangeo.2017.08.018.

Lublin Development Strategy for 2013-2020. Retrieved January 08, 2019, from https://bip.lublin.eu/gfx/ bip/userfiles/_public/import/urzad-miasta-lublin/ogloszenia/konsultacje-spoleczne/2013/konsu 1tacje-spoleczne-z-miesz/74686_strategia_rozwoju_lublina_na_lata_2013_2020_konsultacje.pdf. Resource document.

Makarewicz-Marcinkiewicz, A. (2015). The holistic concept of sustainable development in strategies of Polish Voivodeships to the Year 2020. Problemy Ekorozwoju, 10(2), 103-113.

Mordak, R., Tetlak, M., \& Rawski, J. (2008). Radom City Development Strategy for 2008-2020, WYG International Sp. z o.o. Retrieved January 08, 2019, from https://www.radom.pl/data/other/strat egia_rozwoju_miasta_radiomia_na_lata.pdf. Resource document.

Mozos-Blanco, M. A., Pozo-Menendez, E., Arce-Ruiz, R., \& Baucells-Aleta, N. (2018). The way to sustainable mobility. A comparative analysis of sustainable mobility plans in Spain. Transport Policy, 72, 45-54. https://doi.org/10.1016/j.tranpol.2018.07.001.

Mueller, N., Rojas-Rueda, D., Cole-Hunter, T., de Nazelle, A., Dons, E., Gerike, R., et al. (2015). Health impact assessment of active transportation: A systematic review. Preventive Medicine, 76, 103114. https://doi.org/10.1016/j.ypmed.2015.04.010.

Mueller, N., Rojas-Rueda, D., Salmon, M., Martinez, D., Ambros, A., Brand, C., et al. (2018). Health impact assessment of cycling network expansions in European cities. Preventive Medicine, 109, 62-70. https://doi.org/10.1016/j.ypmed.2017.12.011.

Munoz, J., \& Anguita, F. (2018). The urban tolls as a determining factor for sustainability and competitiveness in urban transport: A study applied to Madrid. Eure-Revista Latinoamericana De Estudios Urbano Regionales, 44(131), 53-74. https://doi.org/10.4067/s0250-71612018000100053.

Olafsson, A. S., Nielsen, T. S., \& Carstensen, T. A. (2016). Cycling in multimodal transport behaviours: Exploring modality styles in the Danish population. Journal of Transport Geography, 52, 123-130. https://doi.org/10.1016/j.jtrangeo.2016.03.010.

Olsson, A. R., \& Davis, D. E. (2017). Expanding the scope of sustainability planning: Lessons from Stockholm's congestion charging policy. Urban Planning, 2(4), 81-92. https://doi.org/10.17645/ up.v2i4.1028.

Opole Development Strategy 2012-2020. Accessed January 08, 2019, from https://prawomiejscowe. um.opole.pl/institution/18386/legalact/1154/GetFile/z549-12.pdf. Resource document.

Otero, I., Nieuwenhuijsen, M. J., \& Rojas-Rueda, D. (2018). Health impacts of bike sharing systems in Europe. Environment International, 115, 387-394. https://doi.org/10.1016/j.envint.2018.04.014.

Pact of Amsterdam, Urban Agenda for the EU. Retrieved January 08, 2019, from https://ec.europa.eu/ regional_policy/sources/policy/themes/urban-development/agenda/pact-of-amsterdam.pdf. Resource document.

Percoco, M. (2013). Strategies of regional development in European regions: Are they efficient? Cambridge Journal of Regions Economy and Society, 6(2), 303-318.

Perez, K., Olabarria, M., Rojas-Rueda, D., Santamarina-Rubio, E., Borrell, C., \& Nieuwenhuijsen, M. (2017). The health and economic benefits of active transport policies in Barcelona. Journal of Transport \& Health, 4, 316-324. https://doi.org/10.1016/j.jth.2017.01.001.

Piatkowski, D. P., Marshall, W. E., \& Krizek, K. J. (2015). Carrots versus Sticks: Assessing intervention effectiveness and implementation challenges for active transport. Journal of Planning Education and Research, 39(1), 50-64. https://doi.org/10.1177/0739456X17715306. 
Pojani, D., Bakija, D., Shkreli, E., Corcoran, J., \& Mateo-Babiano, I. (2017). Do Northwestern and Southeastern Europe share a common "cycling mindset"? Comparative analysis of beliefs toward cycling in The Netherlands and balkans. European Journal of Transport and Infrastructure Research, 17(1), 25-45.

Poland's National Spatial Planning Concept. January 08, 2019, from https://www.wzs.wzp.pl/sites/defau lt/files/files/19683/89272000_1412985316_Koncepcja_Przestrzennego_Zagospodarowania_Kraju 2030.pdf. Resource document.

Poland's National Transport Policy. Retrieved January 08, 2019, from https://chronmyklimat.pl/downl oad.php?id=109. Resource document.

Poland's National Urban Policy 2023. Retrieved January 08, 2019, from https://pte.pl/pliki/2/21/Krajo waPolitykaMiejska.pdf. Resource document.

Poznań City Development Strategy 2020+. Retrieved January 08, 2019, from https://www.poznan.pl/ $\mathrm{mim} / \mathrm{public} / \mathrm{main} /$ attachments.att $? \mathrm{co}=$ show \&instance=1017\&parent=80839\&lang=pl\&id=234811. Resource document.

Programme of sustainable development of the bicycle road system in the area of the city of Płock until 2033 in national, regional and local terms. Retrieved January 08, 2019, from https://dane.plock.eu/ bip/dane/komunikaty/07092011/p_02.pdf. Resource document.

Pucher, J. (1997). Bicycling boom in Germany: A revival engineered by public policy. Transportation Quarterly, 51(4), 31-46.

Pucher, J. (1998). Urban transport in Germany: Providing feasible alternatives to the car. Transport Reviews, 18(4), 285-310. https://doi.org/10.1080/01441649808717020.

Pucher, J., \& Buehler, R. (2008). Making cycling irresistible: Lessons from the Netherlands. Denmark and Germany. Transport Reviews, 28(4), 495-528. https://doi.org/10.1080/01441640701806612.

Pucher, J., Buehler, J., \& Seinen, M. (2011a). Bicycling renaissance in North America? An update and reappraisal of cycling trends and policies. Transportation Research Part A: Policy and Practice, 45(6), 451-475. https://doi.org/10.1016/j.tra.2011.03.001.

Pucher, J., \& Dijkstra, L. (2000). Making walking and cycling safer: Lessons from Europe. Transportation Quarterly, 54(3), 25-50.

Pucher, J., Dill, J., \& Handy, S. (2010). Infrastructure, programs, and policies to increase bicycling: An international review. Preventive Medicine, 50(Suppl), S106-S125. https://doi.org/10.1016/j.ypmed .2009.07.028

Pucher, J., Garrard, J., \& Greaves, S. (2011b). Cycling down under: A comparative analysis of bicycling trends and policies in Sydney and Melbourne. Journal of Transport Geography, 19(2), 332-345. https ://doi.org/10.1016/j.jtrangeo.2010.02.007.

Rerat, P. (2018). Cycling to work: Meanings and experiences of a sustainable practice. Transportation Research Part A: Policy and Practice. https://doi.org/10.1016/j.tra.2018.10.017. (in press).

Ricci, M. (2015). Bike sharing: A review of evidence on impacts and processes of implementation and operation. Research in Transport Business \& Management, 15, 28-38. https://doi.org/10.1016/j.rtbm.2015.03.003.

Rojas-Rueda, D., de Nazelle, A., Tainio, M., \& Nieuwenhuijsen, M. (2011). The health risks and benefits of cycling in urban environments compared with car use: Health impact assessment study. British Medical Journal. https://doi.org/10.1136/bmj.d4521.

Ruda Śląska City Development Strategy for 2014-2030. Retrieved January 08, 2019, from http://rudas laska.pl/theme/rudaslaska/uploads/Strategia_rozwoju_miasta_ruda_slaska_2014-2030.pdf. Resource document.

Ruksza, B., Kapsa, J., Narolska, M., \& Urbańczyk, M. (2016). Czestochowa Development Strategy $2030+$. Retrieved January 08, 2019, from https://czestochowa.pl/page/fie.php?id=5170. Resource document.

Schneider, O., \& Grochowski, C. (2017). Concept of development of cycling communication in Torun for 2017-2023. Retrieved January 08, 2019, from konsultacje.torun.pl/sites/default/files/pictures/2016/ konc_rozw_kom_rower_w_toruniu_2017-2023_ks_2_etap.pdf. Resource document.

Spinney, J. (2010). Mobilising sustainability: Partnership working between a pro-cycling NGO and local government in London. In M. Peters, S. Fudge, \& T. Jackson (Eds.), Low carbon communities: Imaginative approaches to combating climate change locally (pp. 89-107). Cheltenham: Edward Elgar.

Strategy for development of the cycling road network in Łódź in 2015-2020 +. Retrieved January 08, 2019, from https://docplayer.pl/34231371-Strategia-rozwoju-sieci-drog-rowerowych-w-lodzi-w-latach.html. Resource document.

Strategy for integrated development of Łódź 2020+, Retrieved January 08, 2019, from https://uml.lodz.pl/ files/public/dla_mieszkanca/strategia_miasta/strategia.pdf. Resource document.

Strategy for sustainable development of the Warsaw transport system until 2015 and beyond. Retrieved January 08, 2019, from https://transport.um.warszawa.pl/sites/default/files/strategia.pdf. Resource document. 
Strategy for the Implementation of the Cycle Route System for Gdańsk (SR STeR). Retrieved January 08, 2019, from https://brg.gda.pl/attachments/article/63/01_sr_ster_tekst.pdf. Resource document.

Strategy of Integrated Development of the City of Rybnik until 2020. Retrieved January 08, 2019, from https://old.rybnik.eu/_files/strategiazintegrowanegorozwojumiastarybnikadoroku2020_projektdok onsultacji1.pdf. Resource document.

Strategy of Integrated and Sustainable Development of the City of Gliwice until 2022. Retrieved January 08, 2019, from https://bip.gliwice.eu/pub/html/um/files/2014-03-20_Strategia_uchwalona\%282\%29. pdf.

Strategy Warsaw 2030, Retrieved January 08, 2019, from http://2030.um.warszawa.pl/wp-content/uploa ds/2018/06/Strategia-Warszawa2030-final.pdf. Resource document.

Sustainable Development Strategy of Gorzów Wielkopolski. for the years 2010-2020. Retrieved January 08, 2019, from https://gorzow.pl/system/obj/20510_Strategia_Zrownowazonego_Rozwoju_Gorzo wa_2010_2020.pdf. Resource document.

Sustainable Development Strategy of the City of Płock until 2030. Retrieved January 08, 2019, from https:// wizjaplocka2030.eu/wp-content/uploads/2018/04/strategia_nova_4.04.2018.pdf. Resource document.

Sustainable Urban Mobility Plan for the City of Rybnik. Retrieved January 08, 2019, from https://docpl ayer.pl/26332578-Plan-zrownowazonej-mobilnosci-miejskiej-dla-miasta-rybnika.html. Resource document.

Szczecin Development Strategy 2025. Retrieved January 08, 2019, from http://bip.um.szczecin.pl/UMSzc zecinFiles/file/_Strategia_Rozwoju_Szczecina_2025.pdf. Resource document.

Szymańska, D. (2013). Settlements Geography [in Polish: Geografia osadnictwa], Wyd. Naukowe PWN

Tapp, A., Davis, A., Nancarrow, C., \& Jones, S. (2016). Great Britain adults' opinions on cycling: Implications for policy. Transportation Research Part A: Policy and Practice, 89, 14-28. https://doi. org/10.1016/j.tra.2016.05.001.

Tarnów City Development Strategy 2020. Retrieved January 08, 2019, from https://tarnow.pl/content/downl oad/260914/file/Strategia_Rozwoju_Miasta_załącznik.pdf. Resource document.

The concept of building recreational bicycle paths in the city of Olsztyn. Retrieved January 08, 2019, from https://olsztyn.eu/fileadmin/dokumenty-strategiczne/koncepcja-rekreacyjnych-drog-rowerowych -tom1.pdf. Resource document.

The concept of the course of bicycle routes for Legnica. Retrieved January 08, 2019, from https://um.bip. legnica.eu/uml/rozwoj-miasta/programy-strategie-pla/19505,Koncepcja-przebiegu-tras-rowerowych -dla-Legnicy.html. Resource document.

Ton, D., Duives, D. C., Cats, O., Hoogendoorn-Lanser, S., \& Hoogendoorn, S. P. (2018). Cycling or walking? Determinants of mode choice in the Netherlands. Transportation Research Part A Policy and Practice. https://doi.org/10.1016/j.tra.2018.08.023. (in Press).

Toruń City Development Strategy to 2020 with a development perspective until 2028. Retrieved January 08, 2019, from https://www.bip.torun.pl/pobierz.php?FileDir=doc\&File=935_10_zal_03.pdf. Resource document.

Transport Development Strategy for Kalisz 2008-2020 with the Transport Development Programme for Kalisz 2008-2013. Retrieved January 08, 2019, from http://bip.kalisz.pl/zamierzenia/strategia140320 08.pdf. Resource document.

Transport policy for the city of Kraków for the years 2016-2025. Retrieved January 08, 2019, from https:// www.bip.krakow.pl/_inc/rada/uchwaly/show_pdf.php?id=83600. Resource document.

Tychy City Development Strategy 2020+. Retrieved January 08, 2019, from https://bip.umtychy.pl/index .php?action=PobierzPlik\&id=161221. Resource document.

Walbrzych Sustainable Development Strategy until 2020. Retrieved January 08, 2019, from https://bip. um.walbrzych.pl/attachments/download/5896. Resource document.

Wang, L. (2018). Barriers to implementing pro-cycling policies: A case study of hamburg. Sustainability, 10(11), 4196. https://doi.org/10.3390/su10114196.

Włocławek City Development Strategy 2020+. Retrieved January 08, 2019, from https://www.bip.um.wlocl .pl/wp-content/plugins/download-attachments/includes/download.php?id=4241. Resource document.

Wrocław Strategy 2030, Retrieved January 08, 2019, from https://www.wroclaw.pl/rozmawia/strategia/Strat egia_2030_2str.pdf. Resource document.

Wrocław's cycling policy. Retrieved January 08, 2019, from www.wroclaw.pl/files/komunikacja/rowery/ polityka-rowerowa-wroclawia.pdf. Resource document.

Publisher's Note Springer Nature remains neutral with regard to jurisdictional claims in published maps and institutional affiliations. 